\title{
PARADOXICAL REPRESENTATION OF FEMALE NARRATION IN THE SPIRIT OF MAK UNGKAI STORY
}

\author{
Tomi Arianto 1 \\ Universitas Putera Batam (UPB), Batam, Indonesia \\ tomi.arianto@puterabatam.ac.id \\ Dairi Sapta Simanjuntak ${ }^{2}$ \\ Universitas Putera Batam (UPB), Batam, Indonesia \\ Dairi@puterabatam.ac.id
}

\begin{abstract}
The story of Mak Ungkai sea ghost is very commonly heard by old generation of Malay people in Batam coast. The sea ghost portrayed as a scary female ghost, disturbing humans, sinking fishing boats, and harassing coastal people. On the other hand, researchers suspected a paradoxical narrative of Mak Ungkai character which is relatively close to nature, preserves the environment, and counter-patriarch. This problem directed to examine more deeply the image of women in this phenomenon to reveal the interpretation behind the story. This research used an ecofeminist approach with the aim of reversing the stereotypes of women narrated by the community against the character of Mak Ungkai and its relation to the environment and nature. According to Shiva (1998), ecocritic is a new cosmology that views nature and women as having relationships that maintain, cooperate and protect one another. By using descriptive qualitative method, researchers collected data in depth interviews and immediately plunged into the community. Interviews were conducted directly with 5 speakers from the indigenous Malay community in Sebulang Island, Batam. The research used recordings and cameras which are then transcribed in narrative texts that are easily understood. The results of the study found that (1) the existence of patriarchal stereotypes through mak ungkai sea ghost story (2) the paradoxical representation of women based on ecofeminist framework behind the story.
\end{abstract}

Keywords: The Sea Ghost Tale, Ecofeminism, Paradoxical.

\section{INTRODUCTION}

Oral literature is appeared and developed in a society and nurtured through the stories from time to time by one generation to the next. The forms of oral literature are usually like myths, legends, and saga. Each story conveyed an aesthetic elements and contained cultural and moral elements in one community. This is related with Hutomo (1991) explanation that the function of oral literature is the enforcing of social norms social control and as a tool for children's education. The moral element that is reflected in oral literature is the background of the regeneration of the story from generation to generation.

In general, literature is created from two basic elements; ethics and aesthetics. Because of these two elements, literature becomes a form that has a high taste value. Literary works come in two forms, namely oral literature and written literature. Teeuw (2010) argued that oral literature does not require direct communication between the creator and connoisseurs, while oral literature usually functions as a literature that is read or delivered together. Oral literature is literature which includes the expression of citizens' literature in a culture that is spread by word of mouth (Danandjaja, 1984). This means that the work developed through communication support. Because oral literature is conveyed by word of mouth sometimes the storyline in oral literature often varies even changing. But behind the many variations of stories the moral and cultural elements behind the story have the same red line. 
Oral literature has a function as a social control and education because it was created from the reflection of the situation, conditions, and manners in social life. The dominant perspective of a particular object sometimes also leads someone to interpret moral values in oral literature in the dominant category. The stereotype of women depicted in an oral work from the perspective of a patriarchal society can also be formed by this oral function. So that, the dominant elements that appear leads to the perceptions about the object view. One of them is found in the enchanting of female ghost characters in oral stories. Women are portrayed as a terrible figure, avoided, considered a strange figure and must be suppressed, as well as the alienation that was built on women in the story.

The construction of this patriarchal system then penetrated the people minds and then created the image of women who are oppressed, submissive, and even considered as others. Bressler (2007) defined that patriarchal is a system that places men as power. The power of men does not have to be physical but also ideologically and thoughtfully. The way of thinking that places the union in the domestic and submissive domains is also an inseparable part of the construction that establishes male dominance. This concept then builds stereotypes about the image of women. Women are seen as inferior, wild, scary and even avoided.

Patriarchy that develops in society is difficult to remove because it has become a hereditary culture. Women's work is always associated with nurturing; men are always associated with work, men have the power to conquer, expand, and be aggressive. Physical differences received are then strengthened by hegemony in cultural structures, customs, traditions, education, and so on. It can be concluded that patriarchy emphasizes the power of the father/husband in terms of dominating, subordinating and discriminating against women; namely dominance of parents (mainly fathers) over children, dominance of husbands over wives, glorification of virginity traditions, female inferiority, differences in male and female stereotypes, and emphasis on female reproductive functions (Sakina \& Dessy, 2017).

This phenomenon of patriarchal construction is also reflected in the myth of the sea ghost for Malay people in Batam. This sea ghost is known as a woman who has a terrible face and often annoys humans. It is said that when she came, she would emit a foul odor and spread without any source. She lived on a beachside rock. She could be transformed into any wild animal. This sea ghost liked to sink fishing boats that often violate restrictions on the sea. These taboos included saying dirty at sea, disposing of animal carcasses everywhere, defecating or defecating indiscriminately at sea, damaging coral reefs, swearing at the sea, fishing fiercely, etc. Sea ghost also often asked for sacrifice to those who ask for wealth and marine products from her. She also haunted the settlements when the community violated the sea restrictions. She ate livestock at sea, and pelted fishermen with poisonous fish. She can also issue a fire in the middle of the sea and then sink a fishing boat with light resembling fire. Mak ungkai sea ghost is a myth that is most feared and avoided by coastal communities, especially Malay people in Batam.

The image of woman depicted in the figure of Mak ungkai above is very thick with its patriarchal nuances. Likewise with the views of the community that unconsciously formed against the female characters reflected in the story. On the other hand, the 
narrative of women imagined from the tale is so thick with its subordination that it has a paradoxical image when traced with an ecofeminism approach. Ecofeminism criticism provides a new dimension regarding the perspective of women. Wiyatmi, Suryaman, \& Swatikasari (2017) defines ecofeminism as a study of thought and feminist movement that seeks to show the relationship between all forms of oppression of humans, especially women, and nature. Ecofeminism views women as culturally related to nature. This study seeks to deconstruct the image of women who are considered as representations of patriarchal construction into a paradoxical perspective. By using an ecocritical approach, women are no longer imagined as submissive, wild, and domesticity but women as guardians of nature. The figure of woman and nature is presented contrary to the naturedestroying act of capitalist men. As Tong (2009) explains that Eco feminists reveal the marginalization of women and nature from men and culture that injures and exploits women, and limits and deforms men, but also encourages to continue towards the killing of mother earth and greed for the earth who gave birth to us.

Based on the phenomena and contra phenomena above this article is restricted from its research. First, researchers aim to reveal how the image of women in patriarchal construction is reflected in the story of Mak Ungkai. Second, how the image is deconstructed then gives birth to a paradox representation of the image of women. To answer both of these problem formulations, researchers used an ecofeminism approach with qualitative descriptive methods. This research was preceded by data collection by interviewing five respondents from the indigenous Malay community. The results of the interview are then transcribed and analyzed according to the research vision. This research departs from Penelitian dasar pemula (PDP) funded by the Ministry of Research and Technology, Republic of Indonesia.

\section{LITERATURE REVIEW}

2.1. Oral literature

Oral literature is part of literary works in the form of literal expressions which are then told generation to generation in the form of legends, myths, fables, and heroic stories (Atmazaki, 2007). Taum (2011) further explained that the main element of oral literature is aesthetics. Taum added oral literature revealed the collective awareness of the local community (mentyfact) about his life, customs and beliefs. One type of oral literature is in the form of folklore or ancient saga stories. Indonesia is very diverse and rich in folklore. This story is anonymous but still exists because the story is continuously passed down from generation to generation. One of them is the spirit of the sea Mak Ungkai the story that can be found in the Malay coastal community. Until now, the story of the sea ghost is told with various variations. However, Mak Ungkai's image remains the same as a female ghost who is frightening, likes to interfere, even kill human. This image is then traced to the concept of the image of woman in patriarchal construction.

2.2. The image of women

Feminism is a theory about the equality of men and women in the political, economic, social; who fight for the rights of women's interests (Sugihastuti, 2010). Feminism in literary research is considered a movement of awareness of the neglection and exploitation of women in society as reflected in literary works. 
Empirically women are created stereotypically as gentle, emotionally and motherly creatures while men are seen as strong, rational, male and mighty (Dagun, 1992). The images arise because of the concept of gender, namely attitudes that are inherent in men and women that are socially and culturally constructed through a long process, gender socialization which is considered as God's provision. An image is a figurre that can be in the form of a picture that many people have about a person, or a visual mental image (shadow) generated by a word, phrase, or sentence as the concept of a woman's image (Fakih, 2003)

The image of women is all forms of mental-spiritual depictions of daily behavior that are reflected by women in various aspects such as psychological and physical aspects. Women's selfimage is reflected in family and community life as social imagery (Sugihastuti, 2010). Self-image in a circle of patriarchal construction leads the image of women to be in a subordinate position, instead placing men as dominative. This image is then confirmed by various empirical phenomena in the form of social law, morality, and cultural law in society. It is reinforces the image of women increasingly massively developed in social life.

\subsection{Ecofeminism}

Ecofeminism is one of the thoughts and social movements that connect ecological issues with women. Ecofeminism was introduced by Francoide d'Aubonne through a book entitled Le Feminisme ou la Mort (Feminism or Death) which was first published in 1974 (Tong, 2009). In his book the relationship between oppression of nature and oppression of women is stated (Tong, 2009). In this case ecofeminism views women as culturally linked to nature. There is a conceptual, symbolic, and linguistic relationship between feminism and ecological issues (Stanton, 2007).

As one type of feminist thought and movement, ecofeminism has the same characteristics, namely to oppose the forms of oppression of women caused by the patriarchal system. However, unlike other feminist studies, ecofeminism offers the broadest and most demanding conception of one's (human) relationship with others (Tong, 2009). Ecofeminism understands the relationship not only of humans with other humans, but also with the nonhuman world, namely animals, plants, even ghost (Tong, 2009). In this connection, humans often destroy natural resources by machines, polluting the environment with poison gas. As a result, according to natural ecofemins, there is also resistance, so that every day humans are impoverished in line with the felling of trees in the forest and the extinction of animal species for species. To avoid all this, according to ecofeminism, humans must strengthen relationships with one another and relations with the non-human world (Tong, 2009).

In explaining the relationship between nature and women, Karen J. Warren stated that (1) there is an important connection between oppression of women and oppression of nature; (2) understanding of nature with this connection is important to get an adequate understanding of oppression of women and oppression of nature; (3) feminist theory and practice must incorporate an ecological perspective; and (4) solving ecological problems must include a feminist perspective (Shiva, 1998).

From the description above reflected that ecofeminism is in two interdependent disciplines, namely ecology which focuses attention on natural and environmental issues, and 
feminism, which pays particular attention to gender issues. As a flow of ecofeminism social thought and movement ideals the existence of human attitudes and actions that pay attention to nature and women. Nature, as is the case with women, is not an inanimate object, it is not an object that is permitted and deserves to be dominated and exploited. Therefore, in interacting with nature and women, we must always maintain harmony and are not justified in regard of being inferior and subordinate.

\subsection{Previous Study}

There are many researches that contributed in developing ideas in this research. First, Journal written by (Goldwyn,2016) entitled A case study in byzantine ecocriticism: zoomorphic and anthomorphic metaphors in the medieval Greek romance. He analyzed 12thcentury Greek Byzantine literary works such as the romance of Theodore Prodromos, Rhodanthe, and Dosicles. According to him, these works often bring up two types of natural metaphors: zoomorphic metaphors and anthomorphic metaphors.

Gasouka (2017) in his journal entitled The Importance of Feminist Ethnography in Modern Folklore Studies wrote his argument about folklore and feminist. According Gasouka explained about ethnography as a cultural picture that has local wisdom through symbols, values, beliefs and community systems. It was in this local wisdom that Gousaka raised the ethnographic-based feminist movement in his modern philosophy.

Unlike Rahadini (2018) with her journal entitled Philosophical meaning of the myth of pregnant and nursing mothers at Dawuhan village, Banyumas. Rahadini discusses the myths about pregnancy and nursing mothers. Myth itself is categorized as oral literature because it is conveyed by word of mouth through a fairy tale or legend that is unknown to the truth. The results of his research showed that there are several restrictions that endanger the fetus related to food and drink. Certain foods and drinks should not be consumed by pregnant women when breastfeeding.

The last journal was written by Arianto (2019) with the title Indoctrination against women in "The Lowland" by Jhumpa Lahiri. This journal is equally uplifting about domestic and submissive women in India. The difference in this journal, Arianto tends to raise about the character of women who are indoctrinated by feminist approaches Barbara Welter. This research is quite inspiring because it is a reference to how the patriarchal system constructs women's thoughts without resistance.

\section{RESEARCH METHOD}

Faruk (2012) said that data collection methods and techniques are basically a set of methods or techniques that are an extension of the human senses because the aim is to collect empirical facts related to research problems. So this type of research is qualitative research because research data in the form of words and sentences from informants. The research location is in Tanjung Kertang village, Sebulang, Batam, Riau Islands.

Data sources for this research are primary data and secondary data. Primary data obtained by doing of observations and interviews. Observations will be carried out by observing and directly involved in the community activities, especially those related to research variables. Then the interview will be asked that have been prepared previously or in-depth interview method. This interview was conducted to obtain information about the object of research. In this case the interview is refered to the informants that has chosen before. They are the 
coastal local's people in Tanjung Kertang. In collecting primary data, it is also equipped with recording. Any information obtained from observations and interviews will be recorded as well as possible. In addition to primary data, this study also used secondary data obtained from literature study result. This literature study included scientific writing about the object of study and other relevant reading sources such as journals, books, newspapers, magazines and articles.

Before entering the data analysis stage, it is necessary to state the variables in this research, namely; (1) the image of woman reflected from the story of Mak Ungkai and (2) the paradoxical of woman behind this folktale. Data analysis for the variables stated above was done through qualitative descriptive techniques detailed as follows:

1) Comparing verbal in the oral folklore of Mak Ungkai in the form of words, phrases and sentences

2) Reconfirming data through interview techniques to the informant

3) Process the data and classify it in a narrative structure scheme in order to get a systematic story line to reach the images of women

4) Interpreting the data found in the narrative structure of the sea ghost makungkai with supporting ecofeminist theory

\section{RESULT AND DISCUSSION}

This research was conducted with data collection techniques in the form of in-depth interviews toward five informants. The five selected are representation of Malay generations in Batam coastal. It is starting from the oldest generation to the current young generation. The first informant named Atuk Kang. Atuk Kang used to work as a fisherman. He is the first generation to open new land in Tanjung kertang village. Atuk Kang is now 107 years old. The second informant was named $\mathrm{Mr}$. Buyung. Until now he still works as a fisherman. At the age of 54 he often had difficulty going to sea because the catch of fish has declined. Aside from going to sea, Mr Buyung has a side job as a wood cutter. The third informant named Uan Jenah was 72 years old. In the past, her husband was a fisherman so that she knew a lot about the tradition of fishing for Malay people, including the story of Mak Ungkai. The fourth informant is Atuk Muhammad Saleh. Mr Saleh is 78 years old ex-fisherman. Currently Mr. Saleh is a boat maker. He is also very familiar with the traditions, prohibitions and rules when going to sea. The fifth Infrorman is named Kharisma. She is still 19 years old and works as a student. She is the daughter of Malay fisherman in Batam. She is also familiar with Malay stories from her parents, including the story of the sea ghost Mak Ungkai.

From the results of interviews that have been conducted, the researcher is interesting that there are two variables analyzed in this research. First, the image of women portrayed through the figure of Mak Ungkai. Second, the paradoxical of women reflected behind the story. The story of Mak Ungkai is very conditional with meaning. When interviewing informants there is an atmosphere of horror implied from each person. Even the informants were half reluctant to tell stories, because it would cast their own shadow when they wanted to go to sea. As a reflection of social phenomena, sea ghost stories are also not just stories but representations of people's point of view. How a character described is what he encounters in everyday life. Likewise the description of Mak Ungkai figure which then gives a perception of the image of woman that seems subordinate. This is because the conception of 
storytelling is constructed by patriarchal perceptions that place women as subordination.

Mak ungkai's story begins with the myth of a sea guard in the form of a female ghost like a devil. It is said that there was a fisherman who always brought an abundant fish resources even though in paceklik (bad) season. When the weather is not good the fisherman still went to sea and brought abundant of fish until he becoming rich. Some people relized that the person asked the sea ghosts help to get abundant results. The consequences that must be received by the fisherman when Mak Ungkai asked for the sacrifice of his loved ones; his wife and child. The person evaded the anger of the sea lord. Every night Mak Ungkai terrorized the community by giving off a foul odor, eating livestock and overthrowing poison fish toward Malay fisherman on the sea. The terror is exacerbated when some people disturbing their homes on the coral rocks. There are also people who take rocks for the foundations of terraced houses or sea water buffer land. One day there was a stranded person known as Sheikh Johan on the edge of beach. The community helped the man who is subsequently known as a spiritual man. The community asked the man to help expel the sea ghosts. Finally the sea ghost no longer bothered the residents after an agreement was held between the spiritual man and the sea ghost. The agreement was in the form of no longer disturbing the existence of Mak Ungkai, not throwing garbage and expletives at sea, and carrying a Malay marker in the form of yellow sirah (fabric) when fishing on the sea.

There are several statements of informants that enrich research data outside the storyline such as abstinence from fishing, how to overcome disturbed sea ghosts, including the depiction of the sea ghost figure behind the story.
Information from informants led researchers to describe the image of women through the figure of a thick sea ghost with patriarchal construction between; domestic, alienation, and subordinate women.

\subsection{The Images of women}

The depiction of sea ghosts who tend describing female figures as the actors is a patriarchal construction that places women as subordinate. Likewise the depicted images increasingly develop discriminatory conceptions of women from the figures of Mak Ungkai. The image of a domestic woman depicted through the figure of Mak Ungkai seen from where the sea ghost lives. Coral rock is a favorite place for Mak ungkai. It can be seen from the statements of Atuk Kang in quotation below:

Antu laot suke sangat bedihi dibatu karang. Semenjak beabad-abad silamlah die besemayam disane. ItuIt uponlo taka de yang nak mengusik. Tempat tu macam tempat tinggal dielah. Kabanye ade duru orang nampak hantu laot tu disane pas dimalam gelap. Die kadang muncul tuk nakot-nakoti manusie.

[Mak Ungkai spirit is really like living on a coral rock. For centuries she lived there, and remained there if no one bothered. The rock is like the house she lives in. It is said that there is person who has seen sea ghosts appearing at night on a rock to frighten the man.]

As a social reflection, this tale is a reflection of social perception especially Malay people. Likewise with the description of sea ghost imaging. She is described as very domestic, where she lives, and no one is allowed to disturb her. Coral is also described as a domestic territory because it will spend much time there. If it is not disturbed, 
the spirit of the sea will remain as a coral watchman for centuries.

The spirit of the sea is also portrayed as foreign figure "others" to be avoided. She is not part of humans and not part of nature that is recognized by humans. In fact, she is considered a human intruder. This was reflected when researchers interviewed Mr. Buyung. He said that "kalo ingat-ingat cerite rang tue tentang antu laot, berat rasenye nak tejon ke ae. Serase ade yang mengiring disampan" [if I remember the story of sea ghost from my parent, it's hard when want to go to the sea. like someone accompany me in the boat]. This quotation shows that the sea ghosts avoided it. Humans do not know that she is as a guardian of the sea but disrupt human activities, including earning a living. Likewise, when Atuk kang said the spelling to ignore the sea ghost, as it is placing the sea ghosts as human destroyers and disturbing them that reflected from the quotation "kutipan Jangan kau lawe jangan kau dakwe jangan kau rosak jangan kau benase" [Don't fight, don't judge, don't break down don't perish]. The quote indicates the position of sea ghosts that are so isolated for Malay people. She is considered a human intruder so it deserves to be eliminated.

The next image is in the form of woman subordination. It can be seen from the description of the shape of the sea ghost described by the community in the following quote:

.....Mak ungkai akan datang ke tempat tinggal orang itu, memakan hewan ternak masyarakat, mengacau masyarakat dengan suare yg nengerikan dan mengeluarkan bau yg tak sedap.

[....Mak ungkai will come to the community settlement, eat community livestock, disturb the community with a terrible noise and give off an unpleasant odor.]

The sign of sea ghost arrival emit a foul odor. This depiction is strongly opposed to the figure of a woman who usually emits a fragrant odor. Mak Ungkai was also portrayed as a frightening figure with a hideous face, in tattered clothes, a bruising whining voice, and an old figure. This depiction of women who are so bad then put women who are so subordinate compared to the general public that is dominant contrary to these characteristics.

\subsection{Paradoxical female depiction.}

The image of women depicted by the people so subordinated above will be deconstructed when it is attracted to the concept of ecofeminism. If deconstructed, sea ghosts in their role are not human disturber. Instead humans are harassing sea ghosts as a representation of nature and the environment. Sea ghosts are manifestations of nature, because nature is women and in this case a woman is presented by the sea ghosts. It can be considered by Atuk Kang statemen said that Hantu laut bukan sekadar mengacau tapi jugak sebagai penunggu dan penjage laot lepas. Sampai mase kini kami percaye akan hal itu. [The Spirit of the sea is not just disturbing people but also as a guardian and watchmen of the high seas. Until now we still believe it exists]. The quotation above clearly described how the relationship between women and nature. Likewise, the position of this greeting woman is considered as an intruder, on the contrary is a natural guardian. From the narrative of tale has also been mentioned that sea ghosts will not disturb humans if humans did not disturb nature and the marine environment. 
Malay people and the nature have a very strong relation reflected from the story of Mak Ungkai. The relationship is implied from the restrictions that are required with local wisdom in it. Another abstinence that may not be violated by the Malay people related to Mak Ungkai's story is to bring metalic objects to the sea. It is reflected in Atuk kang's statement in the following quotation:

Ade pantangan yg mesti di jage ketike melaot, janga membawak bende berlogam yg melekat di badan, bende berlogam semacam rantai, cincen dan subang. Kalau lelaki pulak tak boleh betendek atau besubang (hehe..), dan itu sangat di hindarkan. Kerane Mak ungkai benci sangat bende tu dibawak dekat laot, cahaye silanye bise memancar dan mengusik keberadaan Mak Ungkai dekat laot

[There is restriction that must be obeyed when going fishing, do not bring metal jewelry in the body, metal jewelry such as chains, rings and earings. if men are not allowed to use earings. (Hehe...), and that is very much avoided. Because Mak ungkai really hates the metal on the sea, the glare emanating from the metal can disturb Mak Ungkai's existence and invite his anger.]

The quote above clearly showed a prohibition using jewelry when fishing. For Malay People it is a taboo thing, on the other hand researchers consider that there is an ecological wisdom that can be drawn from the myth. Precious objects are not appropriate to carry when at sea. Heavy physical activity will be very vulnerable for users to lose valuable objects. The vast sea is not easy to find lost objects and the result is only regret. Humans must be able to distinguish places and situations when carrying out any activity, including carrying jewelry when fishing.

Instead of prohibition, the nature and humans intimacy in an ecological framework can be seen from the advice when going to sea. It is illustrated in Atuk Kang's statement below:

Untuk menjage diri tak di kacau hantu laot, nelayan kene teros ingat pade yg kuase, hal lain semacam membawe nasi, bawang atau lade dekat sampan, menyisekan ae puteh dan membawe sediket kaen kuning.

[To protect themselves from the chaotic sea ghosts, fishermen must remember God, other things such as bringing rice, onions or chillies near the boat, leaving behind white water and carrying a little yellow cloth.]

The quotation explained the traditions of Malay people when fishing. It is also inseparable from the existence of the spirit Mak Ungkai. In public perception, Mak Ungkai's character is a troubling antagonistic character. Rice, onions, chilies, water and a piece of yellow cloth are antidotes so as not to be disturbed by Mak Ungkai. On the other hand, this recommendation actually also contains a preparation so that Malay people will not run out of supplies when fishing. Yellow fabric is the color symbols that are often used by Malay people. Usually a yellow cloth is also worn to cover the gravestone. Both have a correlation, the yellow color on the grave as a marker so as not to mix with other stones, especially when it is dark. The yellow flag or a piece of yellow cloth can also be used as a marker when fishermen get lost in the middle of the sea. Not only the prohibition and recommendations, Mak ungkai story also brings a lot of local wisdom to Malay people, especially related to ecological sustainability. 
From the analysis above it can be seen tha The spirit of Mak Ungkai was seen on the one hand as an antagonist by the Malay community. The spirit is considered as creatures that interfere with and fight humans so it is worth removing or avoiding. Sea ghosts are often thought to damage the economy of the community, sink fishing boats, and frighten people with a variety of bad images that he has. Sea ghosts are also seen as submissive, subordinate, and alienated women. It's very different if you judge it from an eco-feminist point of view. Mak Ungkai is not only a protector of nature but also savior of humans from various dilemmas of natural and environmental damage. This sea ghost comes as a reminder that nature is a friend of man, not an enemy or a place worthy of being exploited by wealth. Likewise, a metaphor for the story of a Malay person who asked Mak Ungkai for help as a pesugihan. On the other hand, humans only exploit the power of sea ghosts but do not want to take responsibility for what they do. This is what invites Mak Ungkai's anger. Nature and humans are something that is interconnected with each other. If humans want the wealth contained in nature, humans must be willing to also take care of that nature in order to remain sustainable.

\section{CONCLUSION}

The story of Mak ungkai sea ghost is phenomenal for the Malay people of Batam. Mak Ungkai is portrayed as the sovereign of the Malay sea. When people heard her name, the public was overshadowed by a horrible and frightening myth. That terrible myth then built people paradigm to avoid even driving away the presence of these sea ghosts. The stigmas of sea ghost images that reflected in the form of women tend to be discredit. Sea ghost is portrayed as evil, murderous, foul-smelling old grandmothers and human bullies. From this narrative, the image of submissive, subordinated and alienated women emerged. This narrative is then further analyzed using the ecofeminism approach. After being deconstructed, the image of the woman depicted earlier is displayed paradoxically. Mak Ungkai was no longer seen as subordinate; instead she was presented as the mother of earth, the guardian of the sea, and human protector from disaster. Mak Ungkai is considered the mother of the earth because she is the representation of a mother who cares and protects the nature. On the other hand, humans who exploit nature are interpreted as patriarchal capitalists who rape their own mother. Mak Ungkai considered as the guardian of the sea was interpreted from prohibitions against Malay people to keep the earth from mak Ungkai's anger. Furthermore Mak Ungkai was presented paradoxically as a human protector because of his role as the guardian of nature so that she could avoid humans from the various disasters that come as a result of their crimes against nature.

\section{ACKNOWLEDGEMENT}

Researchers want to say best regard to the Ministry of Research and Technology for the opportunity toward researchers to receive and implement Penelitian Dasar Pemula (PDP) entitled "Struktur Naratif dan Kearifan Ekologis dalam Sastra Lisan "Hantu Laut Mak Ungkai". This article is the second variable of PDP research result by raising and developing the topic. This article is the achievement of the research output that have been committed by researchers when submitting this grant proposal. Acknowledgments also the researchers convey to LPPM Putera Batam University and Putera Batam University who have helped and 
facilitated researchers running of this research.

\section{REFERENCES}

Adam J. Goldwyn. (2016). A Case Study in Byzantine Ecocriticism: Zoomorphic and Anthomorphic Metaphors in the Medieval Greek Romance. ISLE: Interdisciplinary Studies in Literature and Environment, 23(2), 220-239. Retrieved from https://doi.org/10.1093/isle/isw036

Arianto, T., \& Ambalegin. (2019). Indoctrination Against Women in "The Lowland" by Jhumpa Lahiri. OKARA: Jurnal Bahasa Dan Sastra, 12(2), 153-166. https://doi.org/http://dx.doi.org/10. 19105/ojbs.v12i2.1935.

Atmazaki. (2007). Ilmu Sastra: Teori dan Terapan. Padang: Citra Budaya.

Bressler, C. E. (2007). Literary Criticism: An Introduction to Theory and Practice 4th-ed. Pearson Education. London: Pearson Education, Inc.

Dagun, S. M. (1992). Maskulin dan Feminin: Pria dan wanita dalam fisiologi, psikologi, seksual, karir, dan masa depan. Jakarta: Rineka Cipta.

Danandjaja, J. (1984). Folklor Indonesia: Ilmu Gosip, Dongeng, dan lain-lain. Jakarta: Grafiti Pers.

Fakih, M. (2003). Analisis Gender dan Transformasi Sosial. Yogyakarta: Pustaka Pelajar.

Faruk. (2012). Metode Penelitian Sastra, Sebuah Penjelajahan Awal. Yogyakarta: Pustaka Pelajar.

Gasouka, M. (2017). The Importance of Feminist Ethnography in Modern Folklore Studies. International Journal of Scientific and Research Publications, 7(12), 541-544. Retrieved from http://www.ijsrp.org/research- paper-1217/ijsrp-p7272.pdf

Hutomo, S. S. (1991). Mutiara yang Terlupakan: Pengantar Studi Sastra Lisan. Surabaya: HISKI Komisariat Jawa Timur.

Rahadini, A. A., \& Rahmat. (2018). Philosophical meaning of the myth of pregnant and nursing mothers at Dawuhan village, Banyumas. EduLite Journal of English Education, 3(2), 190-195. https://doi.org/http://dx.doi.org/10. 30659/e.3.2.188-195

Sakina, A., \& Dessy. (2017). Menyoroti budaya patriarki di Indonesia. Share Social Work Journal, 7(1), 71-79.

https://doi.org/10.24198/share.v7i1. 13820

Shiva, V. (1998). Bebas dari pembangunan: perempuan, ekologi dan perjuangan hidup di India. Terj. Hira Jhamtani. Jakarta: Yayasan Obor Indonesia.

Stanton, R. (2007). Teori Fiksi Robert Stanton. Diterjemahkan oleh Sugihartuti dan Rossi Abi Al Irsyad. Yogyakarta: Pustaka Pelajar.

Sugihastuti. (2010). Kritik Sastra Feminisme, teori, dan aplikasinya. Yogyakarta: Pustaka Pelajar.

Taum, Y. Y. (2011). Studi Sastra Lisan: Sejarah, Teori, Metode, dan Pendekatan Disertai Contoh Penerapannya. Yogyakarta: Lamalera.

Teeuw, A. (2010). Sastra dan Ilmu Sastra: Pengantar Teori Sastra. Jakarta: Dunia Pusat Jaya.

Tong, R. (2009). Feminist Though: Third Edition (3rd ed.). Colorado: Westview Press.

Wiyatmi, Suryaman, M., \& Swatikasari, E. (2017). Ekofeminisme: Kritik Sastra Berwawasan Ekologis dan feminis. Yogyakarta: Cantrik Pustaka. 
